\title{
2 War and Displacement: Children as Victims of Mass Violence and Armed Conflict
}

"In history," as German historian Karl Heinz Metz remarked, "there is always violence - and always the pursuit of peace."21 The latter has never been reached in a universal or ideal form, however, since war seems to be the common determinant of human interrelationships, as collective violence against other fellow humans was and still is the center of or base for many aspects of our lives. According to Metz,

[f]rom violence all religion and all politics emerge: religion as an attempt to provide a symbolic answer to the question of why people cannot get rid of violence, politics as an attempt to come to terms with violence in practice through a rule that can tame it. And yet violence never disappears, neither in the state, which is unable to secure internal peace without threats and violence, and which uses violence externally, like war, often excessively, nor in religion, which also becomes violent against heretics and pagans as soon as it prepares to order society according to its values. ${ }^{22}$

The German historian also emphasizes that, considering its position with regard to social norms, violence is nothing moral or immoral per se, but societies tend to organize violence to use it for specific purposes, e.g. the creation of control, power, and dominance. War as such is probably the most violent form of collective human action, as it is "collective action of the living, the purpose of which is to make the living dead. It is the most intense form of such action among people, because it is under the sign of death, which can only be averted by standing together unconditionally. Military violence is socially exercised, socially legitimized violence." 23 Our use of violence and cruelty is often justified - by a religious, political, or moral cause - while the use of violence against us is considered criminal and unjust. ${ }^{24}$ Since world history is first and foremost the history of war, ${ }^{25}$ these moral evaluations of violence and war are not uncommon, and people often demand legitimization for killing each other. The destructive impact of war and collective violence in its different contexts, however, does not end with the peace treaties, which only seem to

21 Karl Heinz Metz, Geschichte der Gewalt: Krieg - Revolution - Terror (Darmstadt: WBG, 2010), 7.

22 Ibid.

23 Ibid., 299.

24 John Keegan, Die Kultur des Krieges (Berlin: Rowohlt Verlag, 1995), 30.

25 Ibid., 545.

Ә Open Access. (C) 2021 Frank Jacob, published by De Gruyter. (c) BY-NC-ND This work is licensed under the Creative Commons Attribution-NonCommercial-NoDerivatives 4.0 International License.

https://doi.org/10.1515/9783110679410-002 
interrupt a history of destruction, because the long-term impact of wars goes far beyond the actual violent conflicts themselves.

Human displacement, on a global scale, is a byproduct of any war. ${ }^{26}$ The Arab Spring(s) in general and the Syrian Civil War in particular have made quite an impact, especially in Europe. ${ }^{27}$ Michael G. Wessells, Professor of Clinical Population and Family Health at Columbia University, sums up the consequences as follows: "The resulting flood of refugees into Europe and other developed areas has created a humanitarian crisis, sparked political conflict, and enabled the rise of right-wing politicians who stand on platforms of fear and xenophobia, including in North America and the European Union."28 And although the people who were forced to leave their homes might have escaped from violence, "[t]here is an obvious humanitarian need for physical necessities, education and health care; however, the disruptions of displacement and migration, and the demands of adaptation to new environments that these entail, also require public health approaches encompassing a wide range of needs." 29 Particularly affected are children, who not only suffer from the actual experiences of loss, forced migration, and violence but whose war-related trauma has the potential to damage their physical and psychological well-being for the rest of their lives. ${ }^{30}$ In addition to the war-torn space they escaped from, the new and different context of their lives "may present new risks for children, both physically and emotionally."31

Australian medical historian John Pearn summed up the war-related experiences of children and the long-term impacts quite well when he wrote that

Children are killed in war by the direct effects of blast, bomb and missile and are injured by burns, gas and rubber bullets. Large numbers die from exposure, disease and starvation. War is one type of catastrophic disaster that ranks, from the perspective of the child, with other disasters, such as earthquake, famine, cyclone and epidemic pestilence. All

26 Michael G. Wessells, "Children and Armed Conflict: Introduction and Overview," Peace and Conflict: Journal of Peace Psychology 22, no. 3 (2016): 198.

27 Cenap Çakmak and Ali Onur Ozçelik, eds. The World Community and the Arab Spring (Cham: Palgrave Macmillan, 2019); Joel Peters, ed. The European Union and the Arab Spring: Promoting Democracy and Human Rights in the Middle East (Lanham, MD: Lexington Books, 2012).

28 Wessells, "Children and Armed Conflict," 198.

29 Rachel Calam, "Public Health Implications and Risks for Children and Families Resettled after Exposure to Armed Conflict and Displacement," Scandinavian Journal of Public Health 45, no. 3 (2017): 209. For a more detailed discussion see the contributions in Lucia de Haene and Cécile Rousseau, eds. Working with Refugee Families: Trauma and Exile in Family Relationships (Cambridge: Cambridge University Press, 2020).

30 Calam, "Public Health Implications," 210.

31 Ibid. 
who have cared for war-enmeshed children, in a professional clinical sense, know how resilient children are. Infants and very young children have the highest mortality, but the ability to forage makes older children sometimes more resilient than adults, for such is the nature of the young of any species. ${ }^{32}$

In short, children often experience war differently, but with regard to its destructive results, they are less likely to survive when they have to face its destruction and different impacts that interrupt their peacetime existence. At the same time, their lives can be destroyed even if they survive: “A proportion of those who survive with life and limb intact inevitably carry the scars of war, of natural disaster, or of refugee existence into their lives and sometimes to the next generation. The few studies of children in the aftermath of war and other catastrophic disasters have documented fear-conditioned responses to the experience of early violence."33

Since wars were never clearly separated from civilians' lives, it is hardly surprising that children have been drawn into the conflicts for centuries, although the intensity of wars and the violence related to them might have impacted young girls and boys even more in the last two centuries. ${ }^{34}$ The children were, however, not only the victims of war, they were also part of those events in many ways, ranging from participants to survivors or even veterans, if they were forced to fight, ${ }^{35}$ be it because they were drawn into the war by ideology or simply due to the necessity to survive somehow. ${ }^{36}$ Regardless of their specific experiences or roles, children probably struggle to actually understand what is happening around them, and for us, as American historian James Marten remarked, "[c]ataloguing the perils of being a child in this war-torn world hardly explains the meaning of conflict in their lives or the meanings they take from

32 John Pearn, “Children and War,” Journal of Paediatrics and Child Health 39 (2003): 167.

33 Ibid., 168. These fear-conditioned responses "include regressive or aggressive behaviour, another long-term legacy of early exposure to the violence of armed conflict. Most adults have had the experience of an unaccustomed food-smell or plant-odour giving one an instant flashback to one's youth. Normally these are pleasurable instant recollections survivors in the human rhinencephalon of the highly developed 'smell-memories' of lower animals. Children who have survived war also experience these - but the triggers are the smell of burning, of bloody wounds and of high explosives." Ibid.

34 James Marten, "Introduction," in Children and War: A Historical Anthology, ed. James Marten (New York: NYU Press, 2002), 2.

35 Ilene Cohn and Guy S. Goodwin-Gill, Child Soldiers: The Role of Children in Armed Conflict (Oxford: Clarendon Press, 2003).

36 Marten, "Introduction," 2-4. For a long-term analysis from the 17th to the 20th century, see the contributions in Dittmar Dahlmann, ed. Kinder und Jugendliche in Krieg und Revolution: Vom Dreißigjährigen Krieg bis zu den Kindersoldaten Afrikas (Paderborn: Schöningh, 2000). 
war. At one level, it is presumptuous of adults, including scholars, to impose their own fears and assumptions on the children of war." ${ }^{37}$ How deep or intense the war experience of children is usually depends on the context, their proximity to the war zone, and the influence of national war propaganda, as children were often educated for violent conflicts in the future. ${ }^{38}$ Considering the latter, it is true, as Marten further emphasized, that "[c]hildren are rarely left to interpret the causes and meanings and ramifications of wars completely on their own."39

The level to which children get involved in actual wars can be quite different and usually depends on the respective context and the identity of the children and/or their parents. ${ }^{40}$ The actual involvement in a war or armed conflict as well as its perception can be quite different, as scholar Mona Macksoud emphasized: "Some children bear arms and/or come under direct fire; some are kidnapped, tortured, brainwashed. As a result, some die or are physically handicapped for life; some children watch in horror as parents, brothers, sisters or friends fight, flee or die; other children see the conflicts only on the television screen." 41 That children need special protection in times of war, especially to prevent them from suffering for their whole lives, seems to be quite obvious and hardly needs a debate from a moral point of view, ${ }^{42}$ especially since children count for a large number of those who suffer from war itself and the forced migration it provokes. ${ }^{43}$ The trauma related to such experiences can hardly be imagined without sharing such memories and, as Michael G. Wessells correctly remarks in this regard,

the full impact of war on children becomes apparent when one considers the enormity of the psychological harm caused to children, the shattering and toxification (rendering them sites of high, unrelieved levels of stress) of their social environments, the lack of access to basic necessities and security, and the loss of important sources of social support for their well-being. Without addressing these issues, large numbers of children

37 Marten, "Introduction," 4.

38 For a case study, see Sabine Frühstück, Playing War: Children and the Paradoxes of Modern Militarism in Japan (Oakland, CA: University of California Press, 2017).

39 Marten, "Introduction," 7.

40 Mona Macksoud, “Children in War,” World Health 47, no. 2 (1994): 21.

41 Ibid. See also Mona Macksoud, J. Lawrence Aber and Ilene Cohn, “Assessing the Impact of War on Children," in Minefileds in Their Hearts: The Mental Health of Children in War and Communal Violence, eds. Roberta J. Apfel and Bennett Simon (New Haven, CT/London: Yale University Press, 1996), 218-230.

42 Mona Macksoud, Helping Children Cope with the Stresses of War: A Manual for Parents and Teachers (New York: UNICEF, 2000) provides an insight into trauma-related problems that need special treatment.

43 Wessells, “Children and Armed Conflict,” 198. 
will be forced to endure preventable suffering, children may be drawn into ongoing cycles of violence, and societies may compromise the development of one of their most precious resources - their children. ${ }^{44}$

War, without any doubt, has an impact on the body and the mind of a child who grows up with and survives a war experience, and studies showed this decades ago.$^{45}$ Although the negative consequences of a child's war experience could have been documented for those who survived the Second World War or the Yugoslavian Civil War, to name just two European examples here, American psychologist Emmy E. Werner argued in 2012 that "we have only limited data on the long-term consequences of differential timing of exposure to war. The evidence that exists suggests that younger children may exhibit more acute symptoms of distress in response to separation from their caregivers; older children may be more traumatized because of their higher exposure to violence and their greater awareness of the negative consequences of armed conflict." ${ }^{26}$ Existent studies have pointed to "a range of mental sequelae" that children who have had to live through war show afterward, including "elevated symptoms of posttraumatic stress disorder (PTSD), depression, and anxiety disorders," and the former of the three "is characterized by the presence of three distinct, but cooccurring symptom clusters: reexperiencing symptoms describe spontaneous intrusions of traumatic memory in the form of images or nightmares; avoidance symptoms involve restricting thoughts and distancing oneself from reminders of the traumatic event; and hyperarousal symptoms include insomnia, irritability, impaired concentration, hypervigilance, and increased startle responses. ${ }^{47}$ Many of these symptoms are associated with a trauma directly or indirectly related to the use of violence in the context of war, which is why it seems to be necessary to spend a moment on the theoretical contextualization of violence here before moving on to the specific context of the Second World War and Jewish children.

Sociologically, although the classic works in the field by Émile Durkheim, Karl Marx, Georg Simmel, and Max Weber leave the term quite contourless, ${ }^{48}$ violence is considered to be a "constitutive problem of social order." ${ }^{49}$ Violence

44 Ibid.

45 Norman Garmezy, "Stressors of Childhood," in Stress, Coping and Development in Children, eds. Norman Garmezy and Michael Rutter (New York: McGraw-Hill, 1983), $43-84$.

46 Emmy E. Werner, “Children and War: Risk, Resilience, and Recovery,” Development and Psychopathology 24 (2012): 553.

47 Ibid.

48 Trutz von Trotha, "Zur Soziologie der Gewalt," in Soziologie der Gewalt, Special issue of Kölner Zeitschrift für Soziologie und Sozialpsychologie 37 (1997): 10-12.

49 Ibid., 10. 
per se, i.e. the act of causing a "physical injury and especially killing other people," 50 is usually not only a physical action but one that creates power that is demonstrated by the act of injuring or killing other people. ${ }^{51}$ And here is one of the essential issues when children become victims of violence - they hardly understand this functionality and will probably only consider it a punishment, often for reasons unknown. While perpetrators and bystanders alike often blur the responsibility for the appliance of violence, the victims, and especially children who find themselves in this position, might develop a guilt complex due to which they identify themselves as responsible for the "punishment" they receive.

Considering the character of violence on the micro and macro level, as presented by German sociologist Peter Imbusch, there are plenty of cases in which children could suffer from it on both levels (Table 1). ${ }^{52}$

Table 1: Violence on the Micro and Macro Levels.

\begin{tabular}{lll}
\hline Micro Level & Macro Level \\
\hline Phenomenology & $\begin{array}{l}\text { Isolated act of violence, punctual } \\
\text { event, threat against or injury of an } \\
\text { individual, e.g. robbery, rape, or } \\
\text { vandalism }\end{array}$ & $\begin{array}{l}\text { Collective organizational context, } \\
\text { e.g. war, genocide, and other forms } \\
\text { of mass destruction }\end{array}$ \\
\hline Type of Violence & $\begin{array}{l}\text { Individual, usually direct violence, } \\
\text { physical or psychological, rather } \\
\text { intentional }\end{array}$ & $\begin{array}{l}\text { Collective or state violence, direct } \\
\text { and structural, politically } \\
\text { motivated, rather functional }\end{array}$ \\
\hline Perpetrator & Individual or small group & $\begin{array}{l}\text { Collective larger group or state } \\
\text { organizations, armies, paramilitary } \\
\text { groups }\end{array}$ \\
\hline Victim & $\begin{array}{l}\text { Single person, individuum without } \\
\text { specific identity }\end{array}$ & $\begin{array}{l}\text { Designated group, selected } \\
\text { according to specific markers/ } \\
\text { identity aspects (imagined or real) }\end{array}$ \\
\hline
\end{tabular}

Another German sociologist, namely Wolfgang Sofsky, remarked that violence as an event destroys time in the sense that human beings' vulnerability forces them to increase the intensity and speed of violence. ${ }^{53}$ At the same time, children are in

\footnotetext{
50 Ibid., 14.

51 Ibid., 48.

52 Peter Imbusch, Moderne und Gewalt: Zivilisationstheoretische Perspektiven auf das 20. Jahrhundert (Wiesbaden: VS Verlag für Sozialwissenschaften, 2005), 31-35.

53 Wolfgang Sofsky, “Gewaltzeit," Soziologie der Gewalt, Special issue of Kölner Zeitschrift für Soziologie und Sozialpsychologie 37 (1997): 102-103.
} 
a way forced to grow up, to be adults in times of conflict, when they are even forced to participate in its destruction, whether as victim or perpetrator. Sofsky added that "[a]lthough every form of violence has a constitutive time that determines its basic structure, the violence itself takes place in time, [and] the situations change and with them their time modes as well." 54 This, especially for children, might mean that their identities rely on the internal dynamics of war, which can force them into different roles in different chronological contexts. The victim of forced migration might end up in a foreign army or in a resistance group and turn his own fate from that of someone being persecuted to a defender of moral values. Depending on the ideological grip of a regime, children might become perpetrators in the name of an ideology and thereby victims of the latter at the same time. ${ }^{55}$ Their experience of violence is furthermore characterized by the places they are encountered. Acts of violence are always possible, although they are possible in different ways, which leaves quite a number of possibilities to characterize them. As harsh as the reality might be, there has also never been a fully non-violent society, ${ }^{56}$ although we judge the level of advancement a society has reached by the security of its weakest, who are, first and foremost, children.

We can hardly deny that violence is an essential part of every society, even if some states managed to create an actual monopoly of violence, i.e. by restricting or prohibiting violence by non-state-sanctioned actors, a condition the state authority bases its organizational claim on. ${ }^{57}$ It is thereby also evident that violence must be considered a "normative, moral, and ethical" 58 category for the union of people in modern societies. And it is the normative compass of these societies that define if violence and its use are considered just or cruel, as German scholar Michaela Christ emphasized: “Changing values and norms, but also changes in body images, have an impact on what is understood collectively and individually as violence. This becomes particularly evident when one regards violence as a form of social practice, i.e. examining in terms of specific practices how actors' specific knowledge of their

54 Ibid., 119.

55 Raul Hilberg has analyzed the different roles, i.e. perpetrator, victim, and bystander, for the history of the Holocaust. Raul Hilberg, Perpetrators, Victims, Bystanders: The Jewish Catastrophe, 1933-1945 (New York: Aaron Asher Books, 1992).

56 Michaela Christ, "Gewaltforschung: Ein Überblick," Aus Politik und Zeitgeschichte 67, 4 (2017): 9-10.

57 Zygmunt Bauman, “Alte und neue Gewalt,” Journal für Konflikt- und Gewaltforschung 2 (2000): 28-42.

58 Christ, "Gewaltforschung," 11. 
world is translated into practice and how this knowledge is created."59 Johann Galtung went even further when he claimed that structural social inequalities could act as triggers for the genesis of physical violence ${ }^{60}$ but was criticized for his concept, which was considered as too vague and too imprecise. As we will see later in the case of the Jewish and non-Jewish children of socialist politicians and activists who were rescued by Ernst Papanek and his supporters, the social identity of the former, in that they were born into the working class and the anti-fascist movement, played a role in their suffering from violence, but this was just one of the categories that established their victimology. The use of force against Jews in Germany or the occupied territories in later years was acceptable for the perpetrators, as it was part of a symbolic form of violence $^{61}$ that had been preached and experienced in Nazi Germany since the days of the Weimar Republic. ${ }^{62}$

While violence was reduced in the Western hemisphere after 1945 and during the Cold War, where the state enforced its grip on the monopoly of violence to contain unwanted outbreaks and violent acts by its people, ${ }^{63}$ the superpower conflict hardly remained "cold" in other parts of the world, ${ }^{64}$ where children in particular were victims of 20th-century great power politics again. ${ }^{65}$ That the

\section{Ibid., 12.}

60 Johan Galtung, “Gewalt, Frieden und Friedensforschung,” in Kritische Friedensforschung, ed. Dieter Senghaas (Frankfurt am Main: Suhrkamp, 1971), 55-104. On its critical perception, see Christ, "Gewaltforschung," 14. See also Michael Rieckenberg, "Auf dem Holzweg? Über Johan Galtungs Begriff der 'strukturellen Gewalt', Zeithistorische Forschungen/Studies in Contemporary History 5 (2008): 172-177.

61 Stephan Moebius and Angelika Wetterer, "Symbolische Gewalt," Österreichische Zeitschrift für Soziologie 4 (2011): 1-10.

62 Frank Jacob, “The Semiotic Construction of Judeo-Bolshevism in Germany, 1918-1933," in War and Semiotics: Signs, Communication Systems, and the Preparation, Legitimization, and Commemoration of Collective Mass Violence, ed. Frank Jacob (London: Routledge, 2020), 106-127. For a specific case study emphasizing the antisemitic continuities from the revolution in 1918/19 to the National Socialist regime, see Frank Jacob, "Der Kampf um das Erbe der Revolution: Die Darstellung Kurt Eisners in den Printmedien der Weimarer Republik," Jahrbuch für Antisemitismusforschung 29 (2020): 325-346.

63 Stefan Kühl, "Gewaltmassen: Zum Zusammenhang von Gruppen, Menschenmassen und Gewalt,” Aus Politik und Zeitgeschichte 67, no. 4 (2017): 22.

64 Immanuel Wallerstein, "What Cold War in Asia? An Interpretative Essay," in The Cold War in Asia: The Battle for Hearts and Minds, eds. Hong Liu, Michael Szonyi and Yangweng Zhen (Leiden/Boston: Brill, 2010), 15-24. See also Frank Jacob, ed. Peripheries of the Cold War (Würzburg: K\&N, 2015).

65 Ann Marie Kordas, The Politics of Childhood in Cold War America (London: Pickering \& Chatto, 2013); Margaret Peacock, Innocent Weapons: The Soviet and American Politics of Childhood in the Cold War (Chapel Hill, NC: The University of North Carolina Press, 2014). 
great powers also intended to keep or extend their standing in the international order consequently and almost naturally led to new conflicts in all parts of the world. ${ }^{66}$ It is obvious that these conflicts caused pain and suffering for countless children, and the many traumata created in the 20th century continue to haunt those who survived the cruelties of war. But one has to confront the issue and include the children's perspective on their own traumata if support should be provided in a meaningful way. ${ }^{67}$ It is important to really understand the children's situation in and after armed conflicts and wars, as the 21st century is no more peaceful than the 19th and 20th centuries. German sociologist Birgitta Nedelmann proposed a typology for a sociology of violence, ${ }^{68}$ which is based on five points, namely 1) the determination of a conceptual frame of reference, including actors, significance, situation in which action takes place, forms of violence, consequences; 2) the conceptual limitation to consider bodily harm; 3) the analysis of reciprocal processes of meaning; 4) the application of a plurality of methods; and 5) the development of a theory of the constitution of social subjectivity. If this is used for the study of children and the forms of violence they are confronted with in wars and armed conflicts, a better understanding of their experiences and traumata might be possible.

Next to the methodological approach, as the German and American scholars Mischa Honeck and James Marten emphasized, "[w]riting a history of war and childhood in the first half of the twentieth century thus means coming to grips with a fundamental paradox: How was it possible for modern societies to imagine childhood as a space of sheltered existence while at the same time accepting the need to mobilize children for war?"69 They argue that children's encounters with war and violence are not modern at all, since young girls and boys have been drawn into conflicts since human beings have existed, however "the scope of their engagement soared with the scale of the global conflicts that dominated the first half of the twentieth century. The period from 1914 to 1945 . . . witnessed dramatic and mutually reinforcing transformations in the histories of war and childhood. Both were shaped by converging forces, including

66 Jost Dülffer, Im Zeichen der Gewalt: Frieden und Krieg im 19. und 20. Jahrhundert (Cologne/ Vienna: Böhlau, 2003), 53.

67 Wessells, "Children and Armed Conflict," 199.

68 Birgitta Nedelmann, "Gewaltsoziologie am Scheideweg: Die Auseinandersetzung in der gegenwärtigen und Wege der künftigen Gewaltforschung," in Soziologie der Gewalt, Special issue of Kölner Zeitschrift für Soziologie und Sozialpsychologie 37 (1997): 72-83.

69 Mischa Honeck and James Marten, "More than Victims: Framing the History of Modern Childhood and War," in War and Childhood in the Era of the Two World Wars, eds. Mischa Honeck, and James Marten (Cambridge: Cambridge University Press, 2019), 3. 
nationalism, imperialism, capitalism, social Darwinism, and the global competition for resources and influence." 70 Of course, one has to be careful not to generalize, as "[t]he engagement of children and youth with war differed according to geography, technology, class, age, race, gender, and the nature of the state in which they lived," ${ }^{71}$ but considering this, it can be said without any doubt that the globalizing phenomenon of the economic penetration of unknown regions of the world has intensified the danger of children and youth being confronted with violence. In addition, the technological advances of humanity with regard to the intention to kill has increased the threat to their lives, as in the 20th century, it was said that "[m]any children are killed by bombs and bullets, others are mutilated by landmines, and many more die as a result of the destruction of health centres, water supplies and the tearing apart of families and communities, with untold psychological effects for generations."72

Even if children survive all that, there is still much to learn about the psychological stress they are suffering from, as their healthy "psycho-social development"73 often becomes impossible, and even if children, like the ones Papanek was able to save from the horrors of Europe during the Second World War, continue to live and have their own careers, they will always be haunted, more or less obviously, by their experiences with violence. While the present book focuses on Ernst Papanek and his work with Jewish refugee children, this only presents one specific case in the terrible history of violence against children and youth during the Second World War. ${ }^{74}$

Their experiences were very diverse, but Berry Mayall and Virginia Morrow argued that "[a]s regards children's experiences during the war, the principal memory in the public mind nowadays is of evacuation."75 Early on, studies discussed

70 Ibid.

71 Ibid., 5.

72 Lynn Barnett, “Children and War,” Medicine, Conflict and Survival 15, no. 4 (1999): 316.

73 Ibid., 317.

74 See, among other works, Swetlana Alexijewitsch, Die letzten Zeugen: Kinder im Zweiten Weltkrieg, transl. by Ganna-Maria Braungardt (Berlin: Suhrkamp, 2016); Margarete Dörr, "Der Krieg hat uns geprägt”: Wie Kinder den Zweiten Weltkrieg erlebten, 2 vols. (Frankfurt am Main: Campus, 2007); Dieter Nelles, Armin Nolzen and Heinz Sünker, “'Kinder des Widerstands' und Politik nach 1945: Die Kinder kommunistischer Widerstandskämpfer gegen das NS-Regime und deren Verhältnis zur Politik nach dem Zweiten Weltkrieg," Bios: Zeitschrift für Biographieforschung, Oral History und Lebensverlaufsanalysen 21, no. 2 (2008): 205-222.

75 Berry Mayall and Virginia Morrow, You Can Help Your Country: English Children's Work during the Second World War (London: UCL Press, 2020), 72. On the Kindertransporte to France and Great Britain, see Claudia Curio, Verfolgung, Flucht, Rettung die Kindertransporte 1938/39 nach Großbritannien (Berlin: Metropol, 2006); Gerda Hofreiter, Allein in die Fremde: Kindertransporte von 
evacuation as one of "children's central and traumatic experiences during the war."76 The experiences of Jewish children were far more diverse because, "just as their parents, [they] were victims of discrimination, ghettoization, deportation, and mass murder."77 These experiences must not be considered "a subset of the adult population," although the "children's experiences are often cast across the arc of the adult narrative."78 It is therefore important to take a closer look at children's war experiences in detail, even if their stories are often reported by adults, as is the case with Papanek as well, as the Austrian pedagogue often wrote about "his" children and what they had to live through. In fact, as American Holocaust scholar Patricia Heberer Rice correctly remarked, "children and juveniles confronted and contended with the Nazis' persecutory policies in markedly different ways. Their experiences were profoundly different from those of their adult contemporaries." ${ }^{79}$ However, these tended to be narrated by adults whether parents or caretakers like Papanek - until some of the children had grown up and presented their own memories. In addition, the sources we have from children and youth related to the history of the Holocaust are mostly written by a specific age group that cannot always be considered as fully representative. ${ }^{80}$ It is therefore not always easy to fully engage with the younger victims of the Holocaust, but numerous works have provided important insights into their history. ${ }^{81}$

Osterreich nach Frankreich, Grossbritannien und in die USA 1939-1941 (Innsbruck: Studien Verlag, 2010); Angelika Rieber and Till Liebertz-Groß, eds. Rettet wenigstens die Kinder: Kindertransporte aus Frankfurt am Main - Lebenswege von geretteten Kindern (Frankfurt am Main: Fachhochschulverlag, 2018).

76 Mayall and Morrow, You Can Help Your Country, 72. For exemplary studies, see Richard Padley and Margaret Cole, eds. Evacuation Survey: A Report to the Fabian Society (London: Routledge, 1940); Susan Isaacs et al., eds. The Cambridge Evacuation Survey: A Wartime Study in Social Welfare and Education (London: Methuen, 1941).

77 Patricia Heberer Rice, "In Their Own Words: Children in the World of the Holocaust," in War and Childhood in the Era of the Two World Wars, eds. Mischa Honeck, and James Marten (Cambridge: Cambridge University Press, 2019), 230.

78 Ibid.

79 Ibid., 230-231.

80 Ibid., 232.

81 Edgar Bamberger and Annegret Ehmann, eds. Kinder und Jugendliche als Opfer des Holocaust: Dokumentation einer internationalen Tagung in der Gedenkstätte Haus der Wannseekonferenz, 12. bis 14. Dezember 1994 (Heidelberg: Dokumentationszentrum Deutscher Sinti und Roma in Zusammenarbeit mit der Gedenkstätte Haus der Wannseekonferenz, 1995); Patricia Heberer, Children during the Holocaust (Lanham, MD: Alta Mira Press, 2015); Feliks Tych et al. Kinder über den Holocaust, frühe Zeugnisse 1944-1948: Interviewprotokolle der Zentralen Jüdischen Historischen Kommission in Polen (Berlin: Metropol, 2009). 
Considering the sociological typology of violence that was discussed before, Jewish children possessed a special victimology because the National Socialist regime "especially targeted the children, who represented the future and the potential of Judaism. The Nazis considered the children special threats because unlike the middle-aged and the elderly, Jewish children had many years ahead of them in which to produce more offspring and renew the ethnic group, thus hindering the Nazi 'Final Solution."”82 Elie Wiesel (1928-2016) remarked with regard to this that Jewish history "continues with Jewish children being massacred by Pharaoh, Nebuchadnezzar and Titus, Haman and Hitler - all

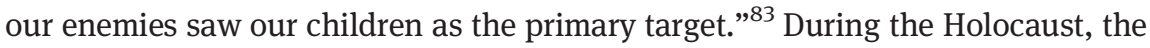
Nazis consequently, as Eric J. Sterling worded it, "by destroying Jewish children, . . . attempted to break a spiritual bond between Jews and God while devastating the parents psychologically." " And the "free world" also did its part, or more accurately did not do its part to save as many children and adults as possible. Regardless of the unwillingness to provide asylum for those who were persecuted by the National Socialist regime, ${ }^{85}$ which would later be criticized by Papanek as well, 10,000 Jewish children were brought to England from Germany and Austria between November 1938 and September $1939 .{ }^{86}$ Some were also brought to France, ${ }^{87}$ where they would find shelter in children's homes, some of which were led by Papanek in Montmorency, a suburb of Paris. Before, they had "watched in horror as their parents were beaten up in the streets, harassed, murdered, or sent off to die in concentration camps" ${ }^{88}$ while being ostracized by Germans and Austrians who claimed that Jewish women, men, and children could no longer be considered a part of their nation and country. The Aryan nation National Socialism sought to create would have no place for its Jewish people and their German heritage and rather intended either to force them out or to destroy them once and for all.

82 Eric J. Sterling, "Rescue and Trauma: Jewish Children and the Kindertransports during the Holocaust," in Children and War: A Historical Anthology, ed. James Marten (New York: NYU Press, 2002), 63.

83 Elie Wiesel, "Keynote Address, Plenary Session of the First International Conference of Children of Holocaust Survivors,” New York, May 28, 1984, cited in ibid.

84 Sterling, "Rescue and Trauma," 63.

85 Eva Schöck-Quinteros, Matthias Loeber and Simon Rau, eds. Keine Zuflucht, nirgends: Die Konferenz von Evian und die Fahrt der St. Louis (1938/39) (Bremen: Institut für Geschichtswissenschaft, Universität Bremen, 2019).

86 Sterling, "Rescue and Trauma," 63-64.

87 Hofreiter, Allein in die Fremde, 81-90.

88 Sterling, "Rescue and Trauma," 64. 
When the latter asked for help, almost nobody responded to rescue them, and in one of the most shameful moments of silence in human history, the fate of millions was doomed by the unwillingness to stand up for the moral values that are supposed to be the basis for our modern societies. And even though 10,000 children were saved from death when they made it to England, while "many children attempted to preserve their Jewish and German heritage, some proved unable to do so because of their need to suppress the hardships they encountered in Germany and because of the favorable treatment they received from their English surrogate parents." 89 Their identities could not be saved, and the children who eventually reached the United States, including the ones Papanek had taken care of for the OSE in France, would face similar issues when they were in a way forced to adapt to a new way of life with their American guest families, where their Jewish past and their experience of violence was supposed to simply disappear. ${ }^{90}$ The Second World War had destroyed not only their homes and past but also their future, and of the 92,000 survivors who reached the United States, the children in particular needed psychiatric care. ${ }^{91}$ Many of them who were "considered Jewish because of their ancestry lost rights as German citizens and were swept up in the Holocaust,"92 and even if they survived the latter, it was impossible for them to mentally heal again after what had been seen, heard, and felt. Papanek realized early on that these children were special and needed special treatment and education, but his ideas were probably too progressive for his time, and the children from the OSE homes, like many others, ended up spread across a country that was supposed to be their new home after the war.

Of course, non-Jewish German children suffered from the war as well and shared some of the named experiences, especially after the Second World War, when destruction and loss were natural parts of their lives, ${ }^{93}$ and after 1943, the Allied Powers "realized that displaced people would pose a formidable problem when the war ended."94 The United Nations Rehabilitation and Relief Administration and the International Refugee Organization were supposed to deal with these

89 Ibid., 65.

90 On the American context of the history of Jewish refugee children, see Christine Hartig, "Grenzen ziehen durch professionelle Hilfe? Transnationale Flüchtlingsarbeit am Beispiel der Immigration unbegleiteter jüdischer Kinder in die USA 1934-1941," WerkstattGeschichte 70 (2015): 7-23.

91 Mary Engel, “Children and War,” Peabody Journal of Education 61, no. 3 (1984): 76.

92 Ibid., 78.

93 Michelle Mouton, "Missing, Lost, and Displaced Children in Postwar Germany: The Great Struggle to Provide for the War's Youngest Victims," Central European History 48, no. 1 (2015): 53-78.

94 Mouton, "Missing, Lost, and Displaced Children in Postwar Germany," 54. 
issues, including providing care for children in the postwar world. ${ }^{95}$ That the intention may have been good but that many issues particularly related to the lives of children and youth were not taken into sufficient consideration can also be shown with regard to the history of Ernst Papanek, who inspected European children's homes for the United Nations after the war as well.

In general, there is a lot to learn from Papanek's work, which the present book will present in part in relation to some of his texts from the 1930s and 1940s. They are of some actuality, especially when one considers that the world is facing similar problems today. Although the " $[\mathrm{t}]$ wo world wars plus the violence and hazards of the world since the 1970s have made empowerment of children an obvious challenge,"96 they are still not protected in a sufficient way. Neither are their traumata addressed in a proper way, and too many children continue to be forgotten by the international community. In 2016, an estimated 65 million people - today there are more than 80 million - were forced to leave their homes, among them ca. 33 million children. ${ }^{97}$ The 21 st century is consequently not so very different from the previous one when one considers how wars and armed conflicts still affect children, especially since they remain targets in many conflicts and can hardly be categorized as bystanders. ${ }^{98}$ Today, they are wounded in similar ways as in the wars of the last century as well, as Barry S. Levy and David Parker emphasized in 2000:

Children are used as civilian shields to protect military forces or as army pack animals. They are imprisoned. They are beaten, wounded, or raped. If fathered by enemy soldiers, they may be rejected by their own mothers. Children are forced to become soldiers, army slaves, or prostitutes under threat of violence or starvation. As soldiers, they are forced to kill people, even family members or friends. Those who survive war may be physically and psychologically maimed for the rest of their lives. As a result of war, children grow up

95 Ibid., 55.

96 Paula S. Fass, “A Historical Context for the United Nations Convention on the Rights of the Child," The Annals of the American Academy of Political and Social Science 633 (2011): 26. Soon after the end of the Second World War, children were suffering again during the Korean War. “Children and War," Social Service Review 25, no. 1 (1951): 91-92. In the Western world, the traumata of many Asian children, who were victims of the Second World War and the related atrocities were often not fully recognized. For an exemplary study, see Margaret D. Stetz, "Reframing the 'Comfort Women' Issue: New Representations of an Old War Crime," in Genocide and Mass Violence in Asia: An Introductory Reader, ed. Frank Jacob (Berlin: De Gruyter, 2019), 61-77.

97 Dragica Mikavica and Chrissie Monaghan, "The Children and Armed Conflict Agenda and Forced Displacement,” Journal of Peacebuilding \& Development 11, no. 3 (2016): 126.

98 Graça Machel, Impact of Armed Conflict on Children (New York, NY: United Nations, 1996), 2. 
without families or homes, without communities or homelands, without a sense of their own or others' humanity. ${ }^{99}$

Children and youth will continue to suffer from growing up in war and from the related consequences ${ }^{100}$ as long as the world community does not find proper ways to protect them, first and foremost by avoiding wars in general. UN Secretary-General Kofi Annan, in a speech to the UN's Security Council, emphasized that " $[\mathrm{t}]$ he question of children and armed conflict is an integral part of the United Nations' core responsibilities for the maintenance of international peace and security, for the advancement of human rights and for sustainable human development." ${ }^{101}$ However, nothing much has changed in the last two decades, because it is still the case that "[a]rmed conflicts affect the development of children from before birth into young adulthood in a myriad of ways, the effects accumulating in interminable civil wars as children grow, and diverting them from normal life pathways in the culture and societies in which they live."102

Until children can really be protected from war and its consequences, as Kendra E. Dupuy and Krijn Peters highlighted in War and Children, they will

bear the brunt of the impact of armed conflict. War destroys the social and economic infrastructure and foundations of society needed for children to grow up into healthy and productive adults. The effects of war on young people are multiple and wide-ranging: they can be separated from their families and communities, they may become unable to access schooling and health services, and they suffer from trauma as the result of witnessing or sometimes participating in atrocities. The increased levels of poverty that are caused by war often entail that young people may be forced to assume new roles, such as income earners or household heads. This in turn has further consequences since children who need to work or take care of siblings lack the money or time to go to school. ${ }^{103}$

The lives and the future of our children are destroyed by wars, a truth Ernst Papanek already understood. He tried to take care of those who had suffered the most, in a time where hope was the only thing that remained. We can therefore learn a lot from Papanek and his work, as well as his writings. That it is important to consider them as valuable contributions to educational and

99 Barry S. Levy and David Parker, "Children and War," Public Health Reports 115, no. 4 (2000): 320.

100 Kendra E. Dupuy and Krijn Peters, War and Children: A Reference Handbook (Santa Barbara, CA: ABC-CLIO, 2009), 19-53.

101 Secretary-General Kofi Annan in a speech to the Security Council, 26 July 2000 cited in Chaditsa Poulatova, Children and Armed Conflict (Newcastle upon Tyne: Cambridge Scholars Publisher, 2012), 1.

102 Poulatova, Children and Armed Conflict, 1.

103 Dupuy and Krijn Peters, War and Children, 49. 
pedagogical strategies to deal with children and youth who have suffered from war should not need any further explanation. When they return home from war, wounded in every sense, it is hard to integrate themselves into their respective communities again. ${ }^{104}$ Papanek realized that when the first children arrived in his OSE children's homes, and due to his progressive pedagogy, the Austrian socialist understood what those children really needed. The following chapter will therefore take a closer look at the man and his work before his texts are presented in the second part of this book.

104 Margaret Angucia, "Children and War in Africa: The Crisis Continues in Northern Uganda," International Journal on World Peace 26, no. 3 (2009): 1. 